\title{
Anatomical segmentectomy of the lung: tip of identifying the intersegmental plane
}

\author{
M Kamiyoshihara ${ }^{{ }^{*}}$, H Igai ${ }^{1}$, T Ibe ${ }^{1}$, N Kawatani ${ }^{1}$, I Shiraishi ${ }^{1}$, K Obayashi ${ }^{2}$, S Nakazawa ${ }^{2}$, Y Ohtaki ${ }^{2}$, K Shimizu ${ }^{2}$, \\ I Takeyoshi ${ }^{2}$
}

From 23rd World Congress of the World Society of Cardio-Thoracic Surgeons

Split, Croatia. 12-15 September 2013

\section{Background}

A pulmonary segmentectomy requires identification of the segmental planes, making it technically more difficult than a lobectomy. Therefore, we present a selective segmental-inflation technique using a butterfly needle. This paper discusses anatomical segmenectomy with special reference to identifying the intersegmental plane.

\section{Methods}

First, the lung is deflated and the pulmonary vessels to the involved segment are divided. The segmental bronchus is divided using a stapling device or ligation. Then, using a butterfly needle, oxygen (approximately $1 \mathrm{~L} / \mathrm{min}$.) is instilled into the targeted bronchus to inflate the involved segment, and the involved segment is severed and removed using electrocautery or a stapling device. The raw surface is covered with an absorbable sealing material to prevent air leaks.

\section{Results}

Fifty-three (M:F = 33:33) patients underwent anatomical segmentectomy with the selective segmental-inflation technique using a butterfly needle. Their median age was 64.9 years. The diseases were malignant lung disease in 52 patients and benign lung disease in 14. The surgical procedure was segmentectomy only in 60 and segmentectomy combined with lobectomy in six. The median operating time was $170 \mathrm{~min}$; the blood loss was $82 \mathrm{~g}$; and the postoperative stay was 8 days. The duration of chest tube drainage was 3 days. No major complication occurred.

\footnotetext{
* Correspondence: micha2005jp@yahoo.co.jp

'Department of General Thoracic Surgery, Maebashi Red Cross Hospital, Maebashi, Japan

Full list of author information is available at the end of the article
}

\section{Conclusions}

In summary, anatomical segmentectomy was performed successfully with the selective segmental-inflation technique using a butterfly needle. Advantages: Surgeons can control every manipulation. No special device is needed; a butterfly needle is sufficient. It is useful regardless of the situation of proximal bronchus. Ultraselective air instillation into the subsegmental bronchus depends on the needle direction. Disadvantages: The proximal site of the targeted bronchus must be identified. Care is needed to avoid systemic air embolism.

\section{Authors' details}

${ }^{1}$ Department of General Thoracic Surgery, Maebashi Red Cross Hospital

Maebashi, Japan. ${ }^{2}$ Gunma University Graduate School of Medicine, Maebashi, Japan.

Published: 11 September 2013

doi:10.1186/1749-8090-8-S1-0226

Cite this article as: Kamiyoshihara et al.: Anatomical segmentectomy of the lung: tip of identifying the intersegmental plane. Journal of Cardiothoracic Surgery 2013 8(Suppl 1):O226.

Submit your next manuscript to BioMed Central and take full advantage of:

- Convenient online submission

- Thorough peer review

- No space constraints or color figure charges

- Immediate publication on acceptance

- Inclusion in PubMed, CAS, Scopus and Google Scholar

- Research which is freely available for redistribution

Submit your manuscript at www.biomedcentral.com/submit
C Biomed Central

\section{Biomed Central}

